\title{
An Index of Mediatisation: Comparing Interest Groups' Political Communication Behaviour
}

\author{
Florian Weiler \\ Department of Social Sciences at the University of Basel \\ florian.weiler@unibas.ch
}

\begin{abstract}
This article investigates the political communication behaviour of interest groups. First, by proposing indices to capture the degree to which mass media have become central for political communication (media logic of communication), and the degree to which conventional strategies aimed at politicians directly govern groups' communication behaviour (political logic of communication). Based on these two indices, the article then proposes an overall index of mediatisation. Second, the article tests three hypotheses regarding the use of the media logic, the political logic, and the mediatisation of interest groups, and finds that group type, resources, and the level of competition all play a role for how strongly interest groups are mediatized. Thus, this article contributes to the scarce empirical research on mediatisation by a) proposing a way to operationalise this concept which can be adjusted using a different set of variables, but can also be applied for different political actors, and b) by showing the usefulness of the constructed indices in an empirical example for Swiss and German interest groups.
\end{abstract}

\section{Keywords}

mediatisation, media logic, political logic, interest groups, lobbying

\section{Medialisierungsindex: Ein Vergleich des politischen Kommunikationsverhaltens von Interessengruppen}

\section{Zusammenfassung}

Dieser Artikel untersucht das politische Kommunikationsverhalten von Interessengruppen. Zunächst werden dabei Indizes vorgeschlagen, mit denen gemessen werden kann, wie zentral die Rolle der Massenmedien für die politische Kommunikation von Interessengruppen ist (Medienlogik der Kommunikation), und wie stark sie auf konventionelle Strategien zur direkten Beeinflussung von Politikern setzten (politische Logik der Kommunikation). Basierend auf diesen beiden Indizes wird dann ein dritter Index für die Mediatisierung abgeleitet. In der Folge werden drei Hypothesen bezüglich Gruppentyp, Ressourcen und Konkurrenzkampf unter Interessengruppen aufgestellt und anhand der verschiedenen Indizes überprüft. Der Artikel trägt daher in zweierlei Linie zur spärlichen empirischen Literatur über Mediatisierung bei. Erstens durch einen Vorschlag zur Operationalisierung des Konzepts, das einfach erweitert bzw. an andere politische Akteure angepasst werden kann. Zweitens wird durch ein Anwendungsbeispiel für Schweizer und Deutsche Interessengruppen die empirische Nützlichkeit der Indizes gezeigt.

\section{Schlüsselwörter}

Medialisierung, Medienlogik, politische Logik, Interessengruppen, Lobbying

The author has declared that no competing interests exist. 


\section{Introduction}

This article analyses the political communication behaviour of interest groups in Germany and Switzerland. Communication techniques and instruments are divided into two categories based on the media logic and the political logic. According to the media logic, interest groups employ techniques typically used by the mass media to gain public attention and, as a consequence, to influence the public discourse and public policy (e.g. Strömbäck 2008; Mazzoleni 2008; Hjarvard 2008). The political logic, on the other hand, is comprised of more traditional lobbying techniques of interest groups such as direct communication with policy makers or events for special target groups and citizens to gain influence (e.g. Strömbäck 2008; Landerer 20I3).

This article suggests two ways how to operationalize the media and the political logic. First, I conduct a factor analysis on a set of variables that are theoretically part of one of the two logics. This analysis confirms that two dimensions, i.e. the two logics, are at the basis of the set of the twelve used variables, and the factor scores for these two factors are used as the first index for the political and the media logic. As a second way to construct these indices, I propose a mathematical way to calculate the degree to which interest groups are governed by the political and the media logic. In addition, mediatisation is introduced in this article as a relative concept: the more strongly the media logic is used compared to the political logic, the more strongly an organisation is considered to be mediatized. Thus, using the indices for the media and the political logic, I am also able to calculate an index for mediatisation. Then I propose various hypotheses why interest groups rely more (or less) on both the political and the media logic. The findings indicate that the group type, the size of the communication department, the budget of an organisation, and the level of competition on an issue are important determinants for the communication behaviour of interest organisation regarding both communication logics, but also that the influence of these variables is, in general, stronger for the media logic.

Dividing organisations' communication techniques into the media logic and the political logic is somewhat related to the concepts of insider and outsider lobbying widely used in the interest group literature (e.g. Beyers 2004; Dür/Mateo 2013; Mahoney 2007). It can be argued that insider lobbying is similar to the political logic, while outsider lobbying is related to the media logic, and I repeatedly draw on this literature in this article. However, there are also significant differences between the two sets of concepts. First, the media logic comprises only techniques that are directly related to the media and media strategies, while outsider strategies also include lobbying techniques such as reaching out to citizens di- rectly, or to organize (public) protests and demonstrations. Second, insider strategies are different from the political logic, as the former would not include elements such as events for target groups and citizens (i.e. people not directly related to the policy making process). Third, both insider and outsider lobbying tactics are mainly concerned about outreach, i.e. how to transmit relevant information to a target recipient, while for the media logic and the political logic information gathering is also crucial, and variables related to gathering information are therefore part of the indices capturing the two logics derived below. Overall, the two ways to categorize political lobbying strategies differ in important ways. Yet while much has already been written about insider and outsider lobbying (e.g. Beyers 2004; Kriesi/Tresch/ Jochum 2007; Weiler/Brändli 2015; Weiler 2016; Weiler/ Reißmann 2019), empirical work regarding the political logic and the media logic is scarce (Riedl/Maurer/Mühl 20I8). Thus, the purpose of this article is to fill this research gap by proposing an empirical way to the political and the media logic, and then by applying these new indices.

\section{Theoretical concepts}

\subsection{Political vs. media logic}

The central topic of this article is the political communication behaviour of interest groups. Strömbäck (2008, 235) emphasises the importance of studying the degree to which the mass media have become central for political communication. He distinguishes between four dimensions on which political communication takes place: a) the degree to which politics is mediated, b) the degree of independence between mass media and political institutions, c) the degree to which media content is governed by a political logic and by a media logic, and d) the degree to which political actors are guided by these same two logics. As this article studies interest groups, the focus of the attention here lies on Strömbäck's fourth dimension, which has been studied already for politicians (Riedl/Maurer/Mühl 20I8).

The media logic, a term first coined by Altheide and Snow (1979), has later been defined by Strömbäck (2008, $233)$ as the "dominance in societal processes of the news values and the storytelling techniques the media make use of to take advantage of their own medium and its own format". Mazzoleni (2008), on the other hand, understands the media logic as the media's role in capturing people's attention. For Hjarvard (2008, I08), the formatting logic that determines how material is categorized, selected, and presented is at the heart of the media logic. In light of Strömbäck's fourth dimension of mediatisation, for political actors the media logic then means 
adapting to the reality of their mediatized environment. The means to accomplish this are to adjust their own communication repertoires to those used by the mass media, which are, in Strömbäck and Esser's (2009, 2I3) words, "simplification, polarization, intensification, personalization, visualization, stereotyping, and particular ways of framing news". In other words, interest organisations following the media logic use journalistic techniques to provide compelling and newsworthy stories, in the hope that these stories (and thus the core message of these organisations) catch on and are further distributed by the mass media. If these stories are well prepared and interesting, journalists, often working under tight schedules, save time and effort when using the provided material. Thus, interest organisations cater to the mass media and follow the commercial logic of these private media enterprises, whose main aim is to sell their product in a competitive environment (Landerer 2013, 243). As a consequence, when interest organisation's communication follows the media logic, format and storytelling techniques shift into the foreground, instead of the actual political message that they want to convey. To be able to provide compelling stories, it is necessary to understand the media environment political organisations are confronted with. Thus, the media logic for political organisations has two components, first providing useful and pre-formatted information to external users, and second gathering information about media content for internal use.

In contrast, the concept of the political logic of communication is less developed. This logic is concerned with collective and authoritative decision-making and the implementation of political decisions (Strömbäck 2008, 233). Parties and politicians are the primary actors, embedded in political institutions, and the main focus lies on issues (Mazzoleni 2008; Strömbäck 2008). Interest groups, on the other hand, are not able to directly make political decisions. Instead, when the communication of interest groups follows the political logic, the aim is to directly influence such political decisions, and thus policy-makers, without the need of the media as intermediaries. Much has been written about why interest groups form (or fail to form) and how groups make decisions collectively, with the underlying assumption that the collective goal is the guiding force of the group (e.g. Schattschneider 1960; Truman 1962, Bolleyer/Weiler 2018). When following the political logic, interest organisations are more interested in directly translating these common goals of their members into policy, and less in more indirect ways of attaining attention by providing compelling stories to news organisations. It follows that groups' political preferences lie at the heart of the political logic. Landerer $(2013,249)$ expresses this differently, stating that for the media logic "the core interest or ultimate goal is to maximize news circulation", while for the political logic "content is more important than presentation". Thus, as is the case for the media logic, the political logic has two dimensions. The first is to gather information about the political environment, while the second consist of communication techniques that directly reach out to political decision-makers and stakeholders.

\subsection{Mediatisation}

Political communication of interest organisations can then be governed by either the media logic or the political logic. Some authors even argue that when politics and political actors are mediatized, the political logic is gradually replaced by the media logic (Meyer 2002; Schrott 2009; Strömbäck 2008). According to Asp (1990; 2014), this represents a power shift within the political system towards the media, resulting in a mediatised society. In contrast to this view, in this article I suggest that the media logic and the political logic of communication can co-exist at the same time. In other words, an organisation can learn to use the tools of the media logic in addition to the more conventional instruments of the political logic. Thus, the media logic is not crowding out the political logic. However, the more strongly the media logic is used compared to the political logic, the more strongly organisations are considered to be mediatized in this article.

According to one classical definition, mediatisation is the "growing intrusion of media into the political domain in many countries" (Mazzoleni/Schulz 1999, 247). The basic assumption of mediatisation is that communication is of growing importance. Mediatisation of politics can thus be defined as a process of social change, in which the relevance of mass media, the coverage of certain topics by the mass media, and thus the media logic, become increasingly more important for the actions of citizens and political actors, such as interest groups. Thus, mediatisation is a dynamic process of social change, in which the influence of the media on actors and other institutions is growing in comparison to non-media actors or institutions (Marcinkowski 20I4). In contrast, the term "mediated politics" has been used to describe a situation in which the media serve as the major vehicle of communication between politicians and citizens (Bennet/Entman 200I). Politics are thus mediated when the media are the major communication channels for politicians; a situation that predates mediatisation (Strömbäck 2008).

Regarding lobby groups, this article follows the view expressed by both Donges (2008) and Vogel (2010), who see mediatisation as a reaction of political organisations to their perception of an increased importance of the media and of communication. Thus, I assume that organisations are able to perceive change in their environment, to make rational decisions that these changes 
are relevant, and to act accordingly. The reaction implies (and becomes visible through) change in the organisational structure (rules and resources for communication) and the organisation's communication behaviour (amount and form of communication output). This communication behaviour can be measured and analysed empirically. In other words, it is possible to operationalize both the political and the media logic, and to construct indices for the political and the media logic, and for mediatisation.

\section{Determinants of usage of political communica- tion repertoires}

First, I discuss how the group type of an interest organisation influences the lobby strategies it uses. Various authors have proposed different ways to categorize interest groups, and all these classifications have their advantages and problems (see Binderkrantz 2008 for a discussion). Here, following Klüver (2OI2), I adopt the classification of interest groups into "cause groups" and "specific interest groups". Cause groups, variously also referred to as public interest groups, mostly pursue goals they believe to be in the common interest, e.g. environmental organisations. Specific interest groups, on the other hand, cater to the needs and preferences of their members only, e.g. labour unions or industry groups. These different groups have been shown to differ strongly in how they lobby, which lobbying strategies they apply, and how they form ties with politicians (Beyers 2004; Binderkrantz/Krøyer 2012; Dür/Mateo 20I3; Maloney 1994; Weiler/Brändli 2015; Weiler/Eichenberger/Mach/Varone 2019). The empirical findings of past research show that cause groups, who represent often very diffuse interests, are faced with a collective action problem, and are therefore constantly struggling to maintain their membership base (Olson 1965). Mobilization strategies and raising public awareness for their concerns are of particular importance to these groups. Media strategies are therefore particularly valuable for cause groups, which is why the expectation is that these groups strongly follow the media logic in their political communication. Specific interest groups have less mobilization problems, since they are often directly concerned with the more tangible (monetary) benefits of their members. They are therefore expected to make less use of the instruments of the media logic. In addition, some researchers believe that specific interest groups are generally better integrated into the policy-making process, because they possess a high level of knowledge about very specific policy areas (Bouwen 2004; Dür/Mateo 2012). They therefore rely more on so-called "insider tactics" such as directly talking to politicians and target groups, and their communication is thus more governed by the political logic. Based on these theoretical considerations, I derive the first set of hypotheses.

H1a: Cause groups make more use of the instruments of the media logic, while specific interest groups apply the instruments of the political logic more often.

H1b: Cause groups are more mediatized than specific interest organisations.

The second set of hypotheses is about an organisation's (communication) resources. Following Schlozman and Tierney (1986), the annual budget is expected to influence an organization's communication repertoire. Both the instruments of the media logic and the political logic are costly to use. Consequently, the higher the spending power of organizations, the more they are able to make use of the expensive instruments of both these logics. Financial resources thus positively influence the degree to which the media logic and the political logic are reflected in interest groups' communication strategies. Yet, while the political logic is more traditional, and its tools better known to (and understood by) leaders of groups and associations, outside expertise is often needed to increase the use of the media logic (Papathanassopoulos/ Negrine/Machini/Holtz-Bacha 2007). However, buying such expertise is only possible for wealthy groups capable to hire expensive media experts, while the knowledge and expertise of the more traditional political logic often already exists even in smaller organizations.

Buying lobbying expertise in the form of communication experts, in turn, does not affect the two communication logics in question equally. Instead, extending an organisation's communication department often goes hand in hand with an increased importance assigned to the mass media (Donges 2008), since communication experts have a better understanding of how mass media work, and how to communicate with them (Papathanassopoulos/Negrine/Machini/Holtz-Bacha 2007). These media experts are already very familiar with the media logic, they have the story-telling techniques internalized, and they know how to strategically select and frame stories to capture the public's attention, just as media organisations (and their journalists) do (Iyengar 1994; Cappella/Jamieson 1997). In short, such media experts lean more heavily to the media logic in their daily work. This argument, then, goes hand in hand with the first argument about financial resources: Money is needed to buy the expertise of communication experts, which is particularly useful for strengthening the media logic, since communication professionals are first and foremost trained to be media experts, and I derive the following hypotheses. 
H2a: More resource rich interest groups apply both the media and the political logic more strongly in their communication behaviour.

H2b: More resource rich interest groups are more strongly mediatized.

As has been pointed out by Austen-Smith and Wright (1992), competition among interest organisations influences their strategic behaviour. The question then, is how competition affects lobby groups' strategic use of the media logic and the political logic. The economic literature indicates that a more intensive competition leads interest groups to generally increase their lobbying activities in order to counter the influence of their opponents (Becker 1983). When competition is very low, on the other hand, interest groups are able to attain their goals even at low levels of lobbying activity. In some cases, such groups are even better off not to engage in too much activity, to avoid raising the attention of the public to a situation favourable to the interest group, but not to society as a whole (Grant 2000; Peltzman 1976; Stigler 197I). Research shows that the number of interest groups active in a specific field, and thus competition among interest groups, varies widely depending on the issue in question (Baumgartner/Leech 200I). Understanding the communication repertoires of the media and the political logic as forms of lobbying, the expectation then is that interest groups make more intensive use of the instruments of both logics as the competition increases. The literature on competition is not very helpful for deriving a clear hypothesis regarding mediatisation. I therefore refrain from formulating such a hypothesis on mediatisation, and only derive one expectation for the media and the political logic.

H3: A higher level of competition in their field of activity compels interest groups to make more use of the communication instruments of both the media and the political logic.

\section{Research design}

\subsection{Dependent variables}

All variables used in this article originate from a survey among all identified Swiss and German interest groups. The final dataset used in this article includes 494 from Switzerland and 446 from Germany. For a description of the survey design and response rates, refer to Appendix A.

First, indices for the political logic, the media logic, and for mediatisation, used as dependent variables in the analysis below, need to be constructed. During the survey respondents had to answer questions regarding their organisation's communication repertoire. The term "repertoire" implies a "limited set of routines that are learned, shared and acted out through a relatively deliberate process of choice" (Tilly 1993, 264). Interest groups "typically use repertoires that enable them to exert pressure on mostly national, sometimes transnational, policy elites, usually without the need for mass mobilization" (Chadwick 2007, 285). For the approach used in this article the focus lies on a specific subset of the broader action repertoires available to political interest groups, i.e. their communication repertoire.

I propose six raw variables to construct the media logic index, and six variables for the political logic index (see Table I). The proposed instruments for the two logics both have components that capture external communication on the one hand, and components designed to gather information about environment on the other hand. The activities and instruments are supposed to capture the entire spectrum of communicational instruments or activities available to interest groups. Survey respondents had to indicate how important each of these repertoires is for their communication, from I ("not important - instrument almost never used") to 5 ("very important - instrument used on a daily basis").

Appendix B, using factor analysis, confirms that these I 2 instruments really follow the two logics of communication. Thus, there are two possibilities to construct the indices for the media logic and the political logic. First, the factor scores can be extracted from the factor analysis for each observation. Organisations making heavy use of those instruments that load highly on the first factor get a high score for the thus derived media logic index. Those who assign high importance the communication repertoires with high loadings on the second factor obtain high scores for the index capturing the political logic. A second way to derive the indices is by applying the formula

$$
\text { Index }_{(\text {political or media })}=\frac{\sum u s e_{i}}{\text { items }} * \frac{\sum\left(\text { use }_{i} * \text { importance }_{i}\right)}{\sum\left(\text { use }_{i} * \text { importance }_{\max }\right)}
$$

where use $_{i}$ indicates that a communication instrument (i) is used by an organisation ( $\mathrm{I}$ if used, o otherwise), items is the total number of instruments in the index, importance $_{i}$ indicates how important a specific instrument is for an organisation, and importance ${ }_{\max }$ is the maximum importance an item can get by construction. Hence, the first part of the formula captures the fraction of the instruments that make up the index an organisation employs, and the second part summarizes how important these used instruments are. For instance, if an organisation only uses two of the six instruments of an index, and assigns medium importance to both of them, then 
Table 1: The communication repertoire of political interest groups

\begin{tabular}{lll}
\hline Communication Instrument/Activity & Mainly governed by & Intended Use \\
\hline Directly approaching journalists & Media logic & External \\
Sending out press releases & Media logic & External \\
Organising press conferences & Media logic & External \\
Press reviews/press services & Media logic & Information gathering \\
Content analysis of press articles & Media logic & Information gathering \\
Recording of Television broadcasts & Media logic & Information gathering \\
\hline Direct contact with political decision-makers & Political logic & External \\
Holding events for special target groups & Political logic & External \\
Holding events with direct contact to citizens & Political logic & External \\
Expert surveys & Political logic & Information gathering \\
Citizen surveys & Political logic & Information gathering \\
Member surveys & Political logic & Information gathering \\
\hline
\end{tabular}

the first part of the formula gets the value $1 / 3$ ( 2 instruments used, divided by 6). The second part of the formula has the value 0.6 (two instruments used and their value being 3 , divided by the two used instruments with the maximum value 5 , so we divide 6 by Io). Overall, the value of the index for the organisation is o.2. The fewer instruments an organisation uses, the smaller the first part of the equation; the less importance it assigns to the used instruments, the smaller the second part of the equation. Since both parts of the equation range from $o$ to $\mathrm{I}$, the maximum of the resulting index is also I, while the minimum is $\mathrm{o}$. This formula can then be applied to construct a second index for both the political logic and the media logic.

Thus, I obtain two indices for the media logic, called "Media logic index (FA)" for the one derived from the factor analysis and "Media logic index (CI)" for the mathematically constructed index, as well as two indices for the political logic, called "Political logic index (FA)" and "Media logic index (CI)". Indeed, the two indices for the same communication logic are highly correlated. The two media logic indices have a correlation of 0.92 , the two political logic indices of 0.98 . This shows that both methods capture the same underlying concept. Using these indices, I construct two mediatisation indices by subtracting the appropriate political logic index from the respective media logic index. The two indices ("Mediatisation index (FA)" and "Mediatisation index (CI)") are again highly correlated with a correlation coefficient of 0.88 . For both these mediatisation indices values larger than o denote that the organisation in question assigns more importance to the media logic, while values below o indicate that the political logic is more relevant.
The larger the value of either index, the more relevant is the media logic, and the stronger an interest group is mediatized.

\subsection{Independent variables}

Group type: 262 of the organisations were coded as cause groups (II8 from Switzerland and I44 from Germany) and 482 as specific interest groups (260 in Switzerland and 222 in Germany). In addition, following Binderkrantz (2008), a category called "Others" was introduced, capturing organisations such as patient associations, scientific societies, religious organisations and hobby groups, as it is unclear whether these groups are cause groups, or whether they mainly cater to the specific needs of their members.

Resources: Resource wealth has two dimensions in relation to political communication. The first is the financial wealth of an organisation. One of the questions in the survey asked for the group's annual budget. As this variable is strongly skewed, the natural logarithm in used in the models below. Another question in the survey pertained to the size of the communication department, the second dimension of resource wealth of interest. Respondents were asked to provide the number of employees working in the communication department of their organisation, or if no such department existed for lack of size of the organisation, how much time by other employees was devoted to political communication (non-integer numbers could be chosen if an organisation had only few employees and none worked on communication full time). Again, this variable is heav- 
ily skewed and the natural algorithm is applied in the analysis.

Competition: Organisations were also asked to assess the level of competition they face by other lobby organisations in their field of activity, from I (very little competition) to 5 (very high competition). There were 92 groups who reported they faced very little competition, 320 stated there was little competition in their field, 347 reported medium competition, while I5I and 30 groups face high and very high competition respectively.

\subsection{Control variables}

In addition to these independent variables, I add the following statistical controls to the models below. The first is the number of members. Large organisations have a harder time communicating directly with their members and the media logic might therefore play a bigger role for such interest groups. Again, this variable is highly skewed and is therefore logarithmized. I also control for the country in which the organisations are active by including a country dummy for Switzerland $(\mathrm{o})$ and Germany $(\mathrm{I})$, as they differ in size and institutional (Weiler/Brändli 2015). Finally, the literature suggests that the issue area in which interest groups are active influences their lobbying behaviour and their lobbying success (Mahoney 2007; Klüver 20II). Hence, the issue area of activity must also be controlled for in the models below. Summary statistics and correlation coefficients for the variables used in this acticle can be found in Appendix C.

\section{Results}

In this section, I describe the results of the statistical models. All regression models, shown in Table 2, use ordinary least squares. The dependent variables derived from the factor analysis are not truncated and approximately normally distributed, hence OLS models are justified. The mathematically calculated indices are bounded between $O$ and I. However, almost all values of these two dependent variables fall somewhere in the middle of the range, and both variables are approximately normally distributed. For this reason, I opt for OLS models for these dependent variables as well.

Group type: Specific interest groups, according to the media logic models I and 2 in Table 2, use the instruments of the media logic significantly less than cause groups. In contrast, these groups are much more governed by the political logic, as the models 3 and 4 show. Finally, models 5 and 6 demonstrate that specific interest groups are much less mediatized than cause groups. Figure I de- picts these effects graphically, using the FA dependent variables. The left-hand panel shows that cause groups are predicted to score about 0.16 higher than specific interest groups on the FA media logic index, a difference of approximately one decile of the variation observed on the dependent variable. It is noteworthy that cause groups are predicted to exhibit positive scores, i.e. these groups use the media logic more often than the average group in the model. In contrast, specific interest groups, on average, have negative values, and thus make use of the instruments of the media logic less often than the average group. This effect is highly significant (for both the factor analysis and the composite index variables).

The effect size is similar for the political logic index, but here the situation is reversed. Specific interest groups are expected to use more of the instruments of the political logic than average, while cause groups use less. Again, the effect comparing the two group types is statistically significant, although for the composite index the effect is significant only at the IO\% level. It is also noteworthy that the interest groups in the "Others" category apply the instrument of both the media and the political logic less often than groups in the other two categories. On the subject of mediatisation, the right-hand panel of Figure I clearly indicates that cause groups are much more mediatized than specific interest groups, with a predicted value of 0.13 , while specific interest groups' predicted mediatisation score of -0.17. This difference is equivalent to a shift from the 45 th to the 6oth percentile of the dependent variable, and is highly significant. Overall, these findings support the expectation that specific interest groups are better integrated into the policy-making process (Bouwen 2004; Dür/Mateo 2012), and therefore are less mediatized than cause groups. Both parts of HI are supported.

Resources: A larger communication department has a positive and significant impact on both the media logic and the political logic, as the models I to 4 of Table 2 demonstrate. In particular, for the media logic the effect is substantial, and even when the communication department is already relatively large, adding additional communication professionals to the team further significantly increases the degree to which the organization's communication adheres to the media logic. This can be seen in the left-hand panel of Figure 2. For the political logic, in contrast, increasing the size of the communication department only has an effect when very few people already work in this area, as the middle panel of Figure 2 demonstrates. Once there are more than three or four people responsible for communication, adding additional communication professionals only weakly increases the usage of the instruments of the political logic. This corroborates the expectation of hypothesis 2 a that larger communication departments lead to an increased use 
Table 2: Determinants of the media and the political logic, and of mediatization

\begin{tabular}{|c|c|c|c|c|c|c|}
\hline & \multicolumn{6}{|c|}{ Dependent variable } \\
\hline & Model 1 & Model 2 & Model 3 & Model 4 & Model 5 & Model 6 \\
\hline & $\begin{array}{l}\text { Media logic } \\
\text { index }\end{array}$ & $\begin{array}{l}\text { Media logic } \\
\text { index }\end{array}$ & $\begin{array}{l}\text { Political logic } \\
\text { index }\end{array}$ & $\begin{array}{l}\text { Political logic } \\
\text { index }\end{array}$ & $\begin{array}{l}\text { Mediatization } \\
\text { index }\end{array}$ & $\begin{array}{l}\text { Mediatization } \\
\text { index }\end{array}$ \\
\hline & $(\mathrm{FA})$ & $(\mathrm{Cl})$ & $(\mathrm{FA})$ & $(\mathrm{Cl})$ & $(F A)$ & $(\mathrm{Cl})$ \\
\hline \multicolumn{7}{|l|}{ Group type (Ref. = Cause groups) } \\
\hline \multirow[t]{2}{*}{ Specific interest groups } & $-0.154^{* * *}$ & $-0.026^{\star *}$ & $0.137^{\star *}$ & $0.019^{*}$ & $-0.291^{* * *}$ & $-0.045^{\star * *}$ \\
\hline & $(0.059)$ & $(0.013)$ & $(0.067)$ & $(0.011)$ & $(0.074)$ & $(0.016)$ \\
\hline \multirow[t]{2}{*}{ Others } & $-0.227^{\star \star *}$ & $-0.045^{\star \star \star}$ & -0.072 & -0.011 & $-0.154^{*}$ & $-0.034^{*}$ \\
\hline & $(0.075)$ & $(0.017)$ & $(0.084)$ & $(0.014)$ & $(0.094)$ & $(0.020)$ \\
\hline \multirow[t]{2}{*}{ Communication staff } & $0.202^{* * *}$ & $0.050^{\star * *}$ & $0.101^{* * *}$ & $0.011^{*}$ & $0.101^{* *}$ & $0.039^{* * *}$ \\
\hline & $(0.034)$ & $(0.008)$ & $(0.038)$ & $(0.006)$ & $(0.042)$ & $(0.009)$ \\
\hline \multirow[t]{2}{*}{ Budget } & $0.155^{\star * *}$ & $0.028^{\star * *}$ & $0.054^{* * *}$ & $0.007^{* * *}$ & $0.102^{* * *}$ & $0.021^{* * *}$ \\
\hline & $(0.012)$ & $(0.003)$ & $(0.013)$ & $(0.002)$ & $(0.014)$ & $(0.003)$ \\
\hline \multirow[t]{2}{*}{ Competition } & $0.010^{* * *}$ & $0.022^{* * *}$ & $0.101^{* * *}$ & $0.012^{* * *}$ & 0.014 & 0.010 \\
\hline & $(0.024)$ & $(0.005)$ & $(0.038)$ & $(0.004)$ & $(0.029)$ & $(0.006)$ \\
\hline \multirow[t]{2}{*}{ Membership } & 0.011 & 0.002 & $0.017^{*}$ & 0.002 & -0.007 & 0.000 \\
\hline & $(0.008)$ & $(0.002)$ & $(0.009)$ & $(0.001)$ & $(0.010)$ & $(0.002)$ \\
\hline \multicolumn{7}{|l|}{ Country (Ref. = Switzerland) } \\
\hline \multirow[t]{2}{*}{ Germany } & $0.315^{\star * *}$ & $0.045^{\star * *}$ & $0.227^{\star * *}$ & $0.038^{* * *}$ & 0.088 & 0.006 \\
\hline & $(0.047)$ & $(0.010)$ & $(0.053)$ & $(0.009)$ & $(0.058)$ & $(0.012)$ \\
\hline \multicolumn{7}{|l|}{ Issue (Ref. = Economic issues) } \\
\hline \multirow[t]{2}{*}{ Social issues } & $-0.317^{\star * \star}$ & $-0.064^{\star \star *}$ & -0.012 & 0.005 & $-0.302^{\star *}$ & $-0.070^{* * *}$ \\
\hline & $(0.100)$ & $(0.022)$ & $(0.113)$ & $(0.009)$ & $(0.125)$ & $(0.027)$ \\
\hline \multirow[t]{2}{*}{ Health issues } & $-0.161^{* *}$ & $-0.032^{*}$ & -0.019 & 0.003 & -0.142 & $-0.035^{*}$ \\
\hline & $(0.076)$ & $(0.017)$ & $(0.085)$ & $(0.014)$ & $(0.094)$ & $(0.020)$ \\
\hline \multirow[t]{2}{*}{ Leisure issues } & 0.036 & -0.007 & -0.182 & $-0.032^{*}$ & $0.219^{*}$ & 0.026 \\
\hline & $(0.098)$ & $(0.022)$ & $(0.111)$ & $(0.018)$ & $(0.123)$ & $(0.026)$ \\
\hline \multirow[t]{2}{*}{ Cultural issues } & -0.041 & -0.018 & 0.109 & 0.021 & -0.150 & -0.039 \\
\hline & $(0.101)$ & $(0.023)$ & $(0.114)$ & $(0.019)$ & $(0.126)$ & $(0.027)$ \\
\hline \multirow[t]{2}{*}{ Educational issues } & $-0.302^{* * *}$ & $-0.052^{* \star *}$ & -0.038 & 0.004 & $-0.264^{\star *}$ & $-0.056^{* *}$ \\
\hline & $(0.081)$ & $(0.018)$ & $(0.091)$ & $(0.015)$ & $(0.101)$ & $(0.022)$ \\
\hline \multirow[t]{2}{*}{ Scientific issues } & $-0.356^{* * *}$ & $-0.093^{* * *}$ & $-0.360 * * *$ & $-0.035^{*}$ & 0.004 & $-0.058^{* *}$ \\
\hline & $(0.101)$ & $(0.023)$ & $(0.114)$ & $(0.019)$ & $(0.126)$ & $(0.027)$ \\
\hline \multirow[t]{2}{*}{ Religious issues } & -0.040 & 0.001 & 0.114 & 0.014 & -0.154 & -0.013 \\
\hline & $(0.176)$ & $(0.039)$ & $(0.198)$ & $(0.033)$ & $(0.220)$ & $(0.047)$ \\
\hline \multirow[t]{2}{*}{ Environmental issues } & $0.195^{\star \star}$ & 0.025 & -0.007 & -0.002 & $0.202^{*}$ & 0.027 \\
\hline & $(0.083)$ & $(0.018)$ & $(0.093)$ & $(0.015)$ & $(0.103)$ & $(0.022)$ \\
\hline \multirow[t]{2}{*}{ Political issues } & 0.052 & 0.001 & -0.188 & -0.028 & $0.242^{*}$ & 0.029 \\
\hline & $(0.108)$ & $(0.024)$ & $(0.121)$ & $(0.020)$ & $(0.134)$ & $(0.029)$ \\
\hline Other issues & -0.356 & 0.016 & -0.265 & -0.053 & -0.092 & 0.07 \\
\hline
\end{tabular}




\begin{tabular}{|c|c|c|c|c|c|c|}
\hline & \multicolumn{6}{|c|}{ Dependent variable } \\
\hline & Model 1 & Model 2 & Model 3 & Model 4 & Model 5 & Model 6 \\
\hline & $\begin{array}{l}\text { Media logic } \\
\text { index }\end{array}$ & $\begin{array}{l}\text { Media logic } \\
\text { index }\end{array}$ & $\begin{array}{l}\text { Political logic } \\
\text { index }\end{array}$ & $\begin{array}{l}\text { Political logic } \\
\text { index }\end{array}$ & $\begin{array}{l}\text { Mediatization } \\
\text { index }\end{array}$ & $\begin{array}{l}\text { Mediatization } \\
\text { index }\end{array}$ \\
\hline & (FA) & $(\mathrm{Cl})$ & (FA) & $(\mathrm{Cl})$ & (FA) & $(\mathrm{Cl})$ \\
\hline & $(0.474)$ & $(0.106)$ & $(0.533)$ & $(0.088)$ & $(0.592)$ & $(0.127)$ \\
\hline \multirow[t]{2}{*}{ Constant } & $-2.401^{* * *}$ & $-0.172^{\star \star \star}$ & $-1.161^{\star \star \star}$ & $0.129 * * *$ & $-1.240 * * *$ & $-0.301^{* * *}$ \\
\hline & $(0.171)$ & $(0.038)$ & $(0.193)$ & $(0.032)$ & $(0.214)$ & $(0.046)$ \\
\hline $\mathrm{N}$ & 940 & 940 & 940 & 940 & 940 & 940 \\
\hline R-squared & 0.386 & 0.324 & 0.131 & 0.096 & 0.139 & 0.155 \\
\hline Adj. R-squared & 0.375 & 0.311 & 0.115 & 0.08 & 0.123 & 0.139 \\
\hline Resid. sd. & 0.667 & 0.149 & 0.75 & 0.124 & 0.833 & 0.178 \\
\hline
\end{tabular}

Notes: Standard errors in parentheses. * $p<0.1,{ }^{* *} p<0.05,{ }^{* * *} p<0.01$

Figure 1: The effect of group type on the media logic (left), the political logic (middle), and mediatisation (right); including $95 \%$ confidence intervals

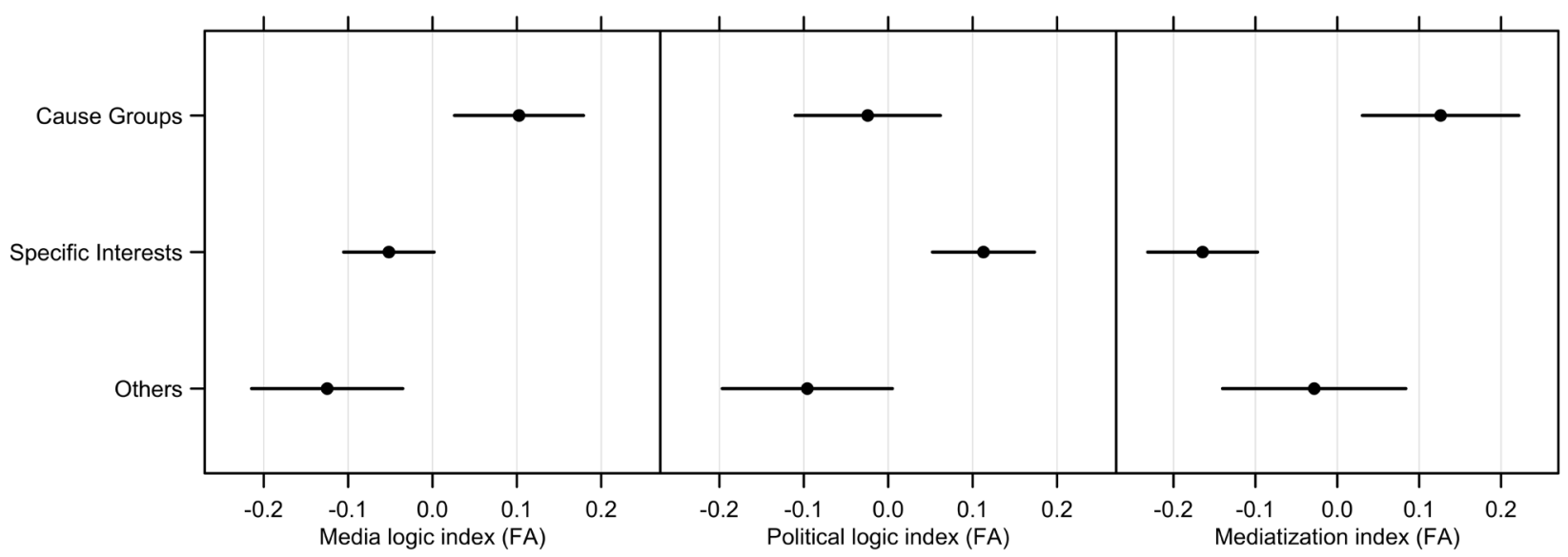

of both logics. It also indicates the media experts hired for communication positions are mostly familiar with the media logic, and therefore focus on the techniques and instruments of this logic (Donges 2008; Papathanassopoulos/Negrine/Machini/Holtz-Bacha 2007). As a consequence, interest groups with more communication staff are also more strongly mediatized, as the models 5 and 6 of Table 2 demonstrate. Organisations with 2 or less communication professionals make more use of the instruments of the political logic relative to the media logic, and are therefore predicted to exhibit negative mediatisation values (see right-hand panel of Table 2). When the communication department gets larger, they exhibit positive mediatisation values. This is further evidence in favour of hypothesis $2 \mathrm{~b}$. All the here-discussed findings are from the factor analysis models, yet the results are very similar for the constructed indices.
The budget is the second variable to capture organisations' resources (Schlozman/Tierney 1986), and further strengthens the just presented findings. The higher the budget of an organisation, the more it uses the instruments of the media logic (models I and 2) and of the political logic (models 3 and 4). As can be seen in the left-hand panel of Figure 3, this effect is particularly strong for the media logic. From the poorest to the richest organisations, the media logic score derived from the factor analysis is predicted to rise from about -0.75 to 0.5 , which is more than a change from the first to the third quartile. For the political logic the effect is much smaller in magnitude (see middle panel of Figure 3), but still highly significant. Indeed, according to the models, the budget effect is the single most important predictor for the usage of both the political and the media logic instruments available to interest organisations. The right- 
Figure 2: The effect of the size of the communication department on the media logic (left), the political logic (middle), and mediatisation (right); including $95 \%$ confidence intervals
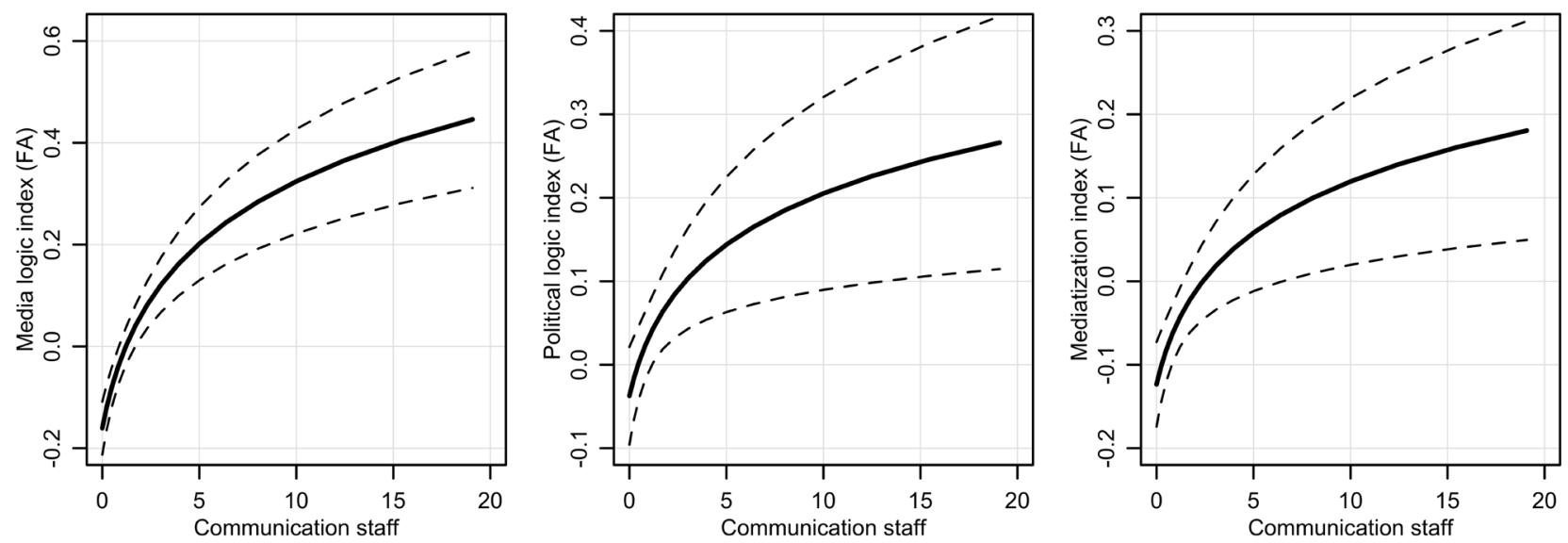

Figure 2: The effect of the size of the communication department on the media logic (left), the political logic (middle), and mediatisation (right); including $95 \%$ confidence intervals
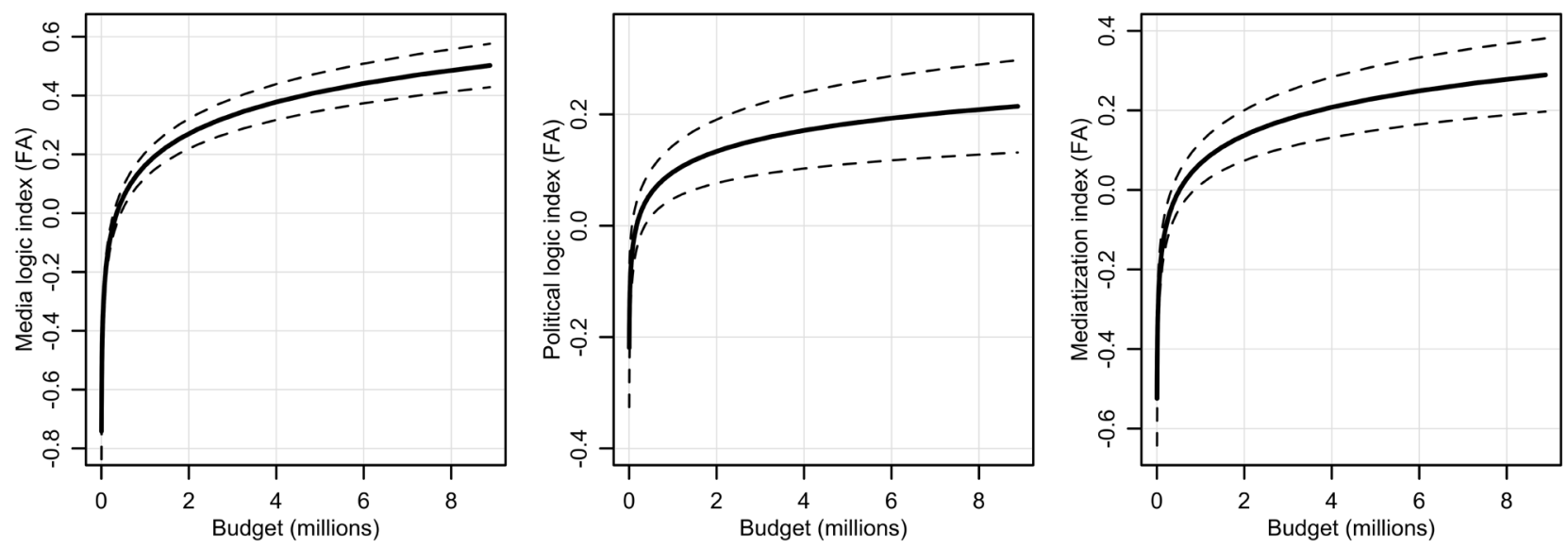

hand panel of Figure 3 demonstrates the effect budget has on mediatisation. The richer interest groups get, the more they rely on the media logic relative to the political logic for their communication. Thus, although both logics are used more often as organisations grow richer, the usage of the media logic instruments grow stronger in importance, and organisations become more mediatized. Thus, both variables used to capture the resource wealth of interest groups corroborate all parts of hypothesis 2 .

Competition: As expected, interest groups facing a higher level of competition generally show more lobbying activity than groups in less competitive environments (Austen-Smith/Wright 1992). As the models I to 4 of Table 2 show, both the instrument of the media and the political logic are used significantly more the stronger the competition is. The effect is significant and substantial across all four models. For instance, in the first model, the loading of the media logic factor is predicted to be about 0.5 points higher for the groups facing the strongest competition when compared to those facing almost none. This corresponds to a change from the mean to the third quantile of this dependent variable. The effect for the political logic is somewhat smaller, but still highly significant. Thus, hypothesis 3 is substantiated. I did not derive a hypothesis for mediatisation because it is unclear a priori whether increased competition should more strongly affect the media logic or the political logic. Models 5 and 6 both reveal a positive effect for competition, meaning that the media logic is more strongly affected by heightened competition levels. However, the effect is not statistically significant. 


\section{Conclusion}

Empirical research on mediatisation is rare (Riedl/Mau$\mathrm{rer} / \mathrm{Mühl}$ 20I8). To fill this research gap, this study first proposes a new way to operationalize mediatisation, and the related concepts of the political and the media logic, which govern the communication behaviour of political actors. The two ways the indices are operationalized in this article - through factor analysis and via a mathematical construct - have been shown to deliver very similar results. The proposed indices, which capture Strömbäck's (2008) fourth dimension of political actor's mediatisation, can easily be improved by using a set of different (or more) variables capturing the media and the political logic. In particular, the media logic could include many variables measuring the usage of the still fast-growing new media such as Twitter and Facebook. The indices, which were measured in this article for interest groups, can also be applied to different political actors, such as political parties or individual politicians. Second, this article demonstrates the usefulness of the indices by testing various hypotheses on group type, resource wealth, and group competition, and thus adds to the scarce empirical knowledge on mediatisation, in this case of interest groups. Thus, this article offers both a theoretical way to empirical capture mediatisation, and an empirical application.

Of course, this study also raises further questions. First, this study is based on date from two countries only, Germany and Switzerland. Both are federal countries with relatively similar economic structures, and close historic and cultural relationships. It is therefore difficult to generalize the findings of this study to other countries that differ in important ways from Germany and Switzerland. Particularly the Swiss case with its many referendums and the way interest groups are integrated into the referendum process makes it hard to draw general conclusions (e.g. Weiler/Brändli 2015). The models in this article already hint at the influence the political setting plays. Swiss interest groups are generally less active regarding both the media and political logic compared to German organisations. Studying different (and more) countries in this regard might be a promising topic for future research. Second, as mentioned, the indices themselves might be improved by including a set of different (or more) variables. In particular, the media logic could include many variables capturing the usage of the growing new media such as Twitter and Facebook, which was not possible in this study for a lack of data. A closer look at these variables and how they affect political communication would be desirable.

\section{References}

Altheide, David/Robert Snow (1979), Media logic, Beverly Hills: SAGE.

Asp, Kent (1990), Medialization, Media Logic, and Mediarchy, in: Nordicom Review, Vol. II(2), 47-50.

Asp, Kent (20I4), News media logic in a New Institutional perspective, in: Journalism Studies, Vol. I5(3), 256-270.

Austen-Smith, David/John Wright (1992), Competitive lobbying for a legislator's vote, in: Social Choice and Welfare, Vol. 9(3), 229-257.

Baumgartner, Frank/Beth Leech (200I), Interest niches and policy bandwagons: Patterns of interest group involvement in national politics, in: The Journal of Politics, Vol. 63(4), II9I-I2I3.

Beauducel, André/Philipp Herzberg (2006), On the performance of maximum likelihood versus means and variance adjusted weighted least squares estimation in CFA, in: Structural Equation Modeling, Vol. I3(2), I86203.

Becker, Gary (1983), A theory of competition among pressure groups for political influence, in: The Quarterly Journal of Economics, Vol. 98(3), 37I-400.

Bennett, Lance/Robert Entman (200I), Mediated Politics: Communication in the Future of Democracy, New York: Cambridge University Press.

Beyers, Jan (2004), Voice and Access Political Practices of European Interest Associations, in: European Union Politics, Vol. 5(2), 2II-240.

Binderkrantz, Anne (2008), Different groups, different strategies: How interest groups pursue their political ambitions, in: Scandinavian Political Studies, Vol. 31(2), I73-200.

Binderkrantz, Anne/Simon Krøyer (2012), Customizing strategy: Policy goals and interest group strategies, in: Interest Groups \& Advocacy, Vol I(I), II5-I38.

Bolleyer, Nicole/Florian Weiler (2018), Why Groups Are Politically Active: An Incentive-Theoretical Approach, in: Comparative Political Studies, Vol. 5I(I2), I628-I660.

Bouwen, Pieter (2004), Exchanging access goods for access: A comparative study of business lobbying in the European Union institutions, in: European Journal of Political Research, Vol. 43(3), 337-369.

Cappella, Joseph/Kathleen Jamieson (1997), Spiral of cynicism: The press and the public good, New York: Oxford University Press.

Chadwick, Andrew (2007), Digital network repertoires and organizational hybridity, in: Political Communication, Vol. 24(3), 283-30I.

Donges, Patrick (2008), Medialisierung politischer Organisationen. Parteien in der Mediengesellschaft, Wiesbaden: VS Verlag für Sozialwissenschaften.

Dür, Andreas/Gemma Mateo (2012), Who lobbies the European Union? National interest groups in a mul- 
tilevel polity, in: Journal of European Public Policy, Vol. I9(7), 969-987.

Dür, Andreas/Gemma Mateo (2013), Gaining access or going public? Interest group strategies in five European countries, in: European Journal of Political Research, Vol. 52(5), 660-686.

Grant, Wyn (2000), Pressure groups and British politics, London: Macmillan.

Hjarvard, Stig (2008), The mediatization of society: A theory of the media as agents of social and cultural change, in: Nordicom Review, Vol. 29(2), I05-I34.

Iyengar, Shanto (1994), Is anyone responsible? How television frames political issues, Chicago, London: University of Chicago Press.

Jöreskog, Karl/Irini Moustaki (200I), Factor analysis of ordinal variables: A comparison of three approaches, in: Multivariate Behavioral Research, Vol. 36(3), 347-387.

Klüver, Heike (201I), The contextual nature of lobbying: Explaining lobbying success in the European Union, in: European Union Politics, Vol. I2(4), 483-506.

Klüver, Heike (2012), Biasing politics? Interest group participation in EU policy-making, in: West European Politics, Vol. 35(5), III4-II33.

Kriesi, Hanspeter/Anke Tresch/Margit Jochum (2007), Going public in the European Union: Action repertoires of Western European collective political actors, in: Comparative Political Studies, Vol. 4O(I): 48-73.

Landerer, Nino (2013), Rethinking the logics: A conceptual framework for the mediatization of politics, in: Communication Theory, Vol. 23(3), 239-258.

Mahoney, Christine (2007), Lobbying success in the United States and the European Union, in: Journal of Public Policy, Vol. 27(I), 35-56.

Maloney, William/Grant Jordan/Andrew McLaughlin (1994), Interest groups and public policy: the insider/ outsider model revisited, in: Journal of Public Policy, Vol. I4(I), I7-38.

Marcinkowski, Frank (2014), Mediatisation of Politics: Reflections on the State of the Concept, in: Javnostthe Public, Vol. 2I(2), 5-22.

Mazzoleni, Gianpietro (2008), Populism and the Media, in: Albertazzi, Daniele/Duncan McDonnell (eds.), Twenty-First Century Populism: The Spectre of Western European Democracy, Basingstoke: Palgrave McMillan, 49-64.

Mazzoleni, Gianpietro/Winfried Schulz (1999), "Mediatization" of politics: A challenge for democracy?, in: Political Communication, Vol I6(3), 247-26I.

Meyer, Thomas (2002), Media democracy: How the media colonize politics, Cambridge: Polity Press.

Oeckl, Albert (2010), Taschenbuch des öffentlichen Lebens: Deutschland 2010, Bonn: Festland Verlag.

Olson, Mancur (1965), The logic of collective action: Public goods and the theory of groups, Cambridge, MA: Harvard University Press.
Papathanassopoulos, Stylianos/Ralph Negrine/Paolo Mancini/Christina Holtz-Bacha (2007), Political Communication in the Era of Professionalisation, in: Papathanassopoulos, Stylianos/Ralph Negrine/Paolo Mancini/Christina Holtz-Bacha (eds.), The Professionalisation of Political Communication: Changing Media, Changing Europe, Bristol, Chicago: Intellect Books, 9-26.

Peltzman, Sam (1976), Toward a more general theory of regulation, in: Journal of Law and Economics, Vol. I9(2), 2 II-24O.

Riedl, Andreas/Birgit Mühl/Peter Maurer (2018), Anpassung an die Medienlogik? Eine Untersuchung politischer Kommunikationsstrategien von AkteurInnen aus Deutschland und Österreich, in: Österreichische Zeitschrift für Politikwissenschaft, Vol. 47(I), I-I6.

Schattschneider, Elmer (1960), The Semisovereign People, New York: Holt, Rinehart and Winston.

Schlozman, Kay/John Tierney (1986), Organized interests and American democracy, New York: Harper \& Row.

Schrott, Andrea (2009), Dimensions: Catch-all label or technical term, in: Lundby, Knut (ed.), Mediatization: Concepts, Changes, Consequences, New York: Peter Lang, 4I-6I.

Schwabe (2009), Publicus 20I0. Schweizer Jahrbuch des öffentlichen Lebens, Basel: Schabe Basel.

Stigler, George (197I), The theory of economic regulation, in: The Bell Journal of Economics and Management Science, Vol. 2(I), 3-2I.

Strömbäck, Jesper (2008), Four phases of mediatization: An analysis of the mediatization of politics, in: The International Journal of Press/Politics, Vol. I3(3), 228-246.

Strömbäck, Jesper/Frank Esser (2009), Shaping politics: Mediatization and media interventionism, in: Lundby, Knut (ed.), Mediatization: Concepts, Changes, Consequences, New York: Peter Lang, 205-224.

Tilly, Charles (1993), Contentious Repertoires in Great Britain, I758-I834, in: Social Science History, Vol. I7(2), 253-280.

Truman, David (1962), The Governmental Process. Political Interests and Public Opinion, Westport: Greenwood Press.

Vogel, Martina (2010), Regierungskommunikation im 2I. Jahrhundert: Ein Vergleich zwischen Großbritannien, Deutschland und der Schweiz, Baden-Baden: Nomos.

Weiler, Florian/Matthias Brändli (2015), Inside versus outside lobbying: How the institutional framework shapes the lobbying behaviour of interest groups, in: European Journal of Political Research, Vol. 54(4), 745766.

Weiler, Florian (2016), Lobbygruppen im politischen Wettbewerb: Die Auswirkungen des Konkurrenzkampfes unter Interessengruppen auf deren Lobbyverhalten, in: Swiss Political Science Review, Vol. 22(3), 32 I-352. 
Weiler, Florian/Jonas Reißmann (2019), Interest group coalitions: How the intensity of cooperation affects the choice of lobbying strategies, in: Interest Groups \& Advocacy, Vol. 8(I), 9I-II9.

Weiler, Florian/Steven Eichenberger/André Mach/Frédéric Varone (2019), More equal than others: Assessing economic and citizen groups' access across policymaking venues, in: Governance, Vol. 32(2), 277-293.

Wonka, Arndt/Frank Baumgartner/Christine Mahoney/ Joost Berkhout (2010), Measuring the size and scope of the EU interest group population, in: European Union Politics, Vol. II(3), 463-476.

\section{Author}

Florian Weiler is a senior researcher in the Department of Social Sciences at the University of Basel. His research focuses on interest groups and their lobbying strategies on the one hand, and (global) environmental governance on the other.

\section{Appendix for "Political Communication: The Use of Media and Political Logics among Swiss and Ger- man Interest Groups"}

\section{Appendix A: Survey method}

Following the method suggested by Wonka et al. (2010), a list of interest groups for Germany and Switzerland countries was compiled using various sources. For Germany, two sources registering lobby groups were used. The first is the Taschenbuch des offentlichen Lebens - Deutschland 2010 (Oeckl 20IO), the second is the list of officially registered lobby organisations with the German Bundestag (the so called "Lobbyliste"). In Switzerland, data collection started with the Schweizer Jahrbuch des öffentlichen Lebens (Schwabe 2009). Since no official registry for interest groups exists in the Swiss parliament, the parliament's "Gästeregister" (guest registry) for relevant organisations was used as a second source of information. Finally, the Swiss list of interest groups was completed by checking the website www.verbaende.ch for potentially relevant organisations not yet included in the list. The different lists were merged, and duplicate entries were deleted. During this coding process the postal, Internet, and email addresses of each group's central office, and (where possible) the Internet and email addresses of the organisation's communication departments were recorded. These email addresses were used as the emaildatabase for the online questionnaire. Data collection started in early $201 \mathrm{I}$ in Switzerland, and in spring 2011 in Germany. The response rate was $40 \%$ for Switzerland ( 985 of 2475 organisations the questionnaire was mailed to) and $23 \%$ for Germany (I246 of 5422 organisations). However, many organisations left information needed for this article blank. For instance, 870 interest groups did not reply to the question of their annual budget - a much higher non-response rate than for any other question (only about 200 organisations did not reply to the question about corporate/group membership - the variable with the second highest number of missing answers). These organisations are therefore excluded from the analysis and the final number of observations is 494 for Switzerland, and 446 for Germany.

All data used in this article are derived from this dataset containing 940 observations, with one exception. No question in the survey allowed the identification of interest groups as being either cause groups or specific interest groups. Therefore, all organisations in the dataset which could be identified were hand-coded as falling into one of the three categories "cause groups", "specific interest groups", "other". As some organisations chose not to provide either Internet or email address and could not be identified, they had to be excluded from the study, which contributed to the reduction of observations described above.

\section{Appendix B: Factor Analysis}

The question asked in this appendix is whether the I2 communication repertoires selected for the study really fall into the two logics of communication - the media and the political logic - as the theory suggests. Employing factor analysis, both the Scree test and the Kaiser criterion reveal that underlying the $\mathrm{I} 2$ variables are two dimensions, or factors. Using an oblique rotation method, the results of the factor analysis show that the theoretical division of the communication instruments into a media logic and a political logic is confirmed. Figure AI shows the result of the factor analysis graphically. The six repertoires belonging to the two logics indeed cluster together. Particularly the six instruments in the political logic all exhibit relatively high loadings for the second factor (only the variable "organizing events for special target groups" has a somewhat lower loading), while their loadings for the first factor are very low. For the communication repertoires theorized as belonging to the media logic the picture is similar. Four variables load highly on the first factor and have very low loadings on the second factor, while one variable ("analysing television broadcasts") has a somewhat lower loading on the first factor. However, there is one variable, "analysing the content of press articles", which according to the factor analysis can neither be attributed to the first or the second factor. Nevertheless, this empirical result in general confirms that the communication techniques used by political interest groups do fall into the two the- 
oretically derived logics, with factor one representing the media logic, and factor two the political logic.

It should be noted here that some authors believe that factor analysis can be problematic with categorical variables (Jöreskog/Moustaki 200I). However, others show that simple maximum likelihood (ML) approaches work well when the variables have at least four categories (see Beauducel/Herzberg 2006). In addition, the two communication repertoires are not independent of each other, but can, in the view of the author of this article, grow in importance at the time, for instance when the budget of an organisation increases. Thus, I opt for an oblique rotation method to allow for this potential correlation of the factors. However, the results are very similar when using an orthogonal rotation method instead.

Figure A1: Factor analysis for the twelve variables capturing organisations' communication repertoires

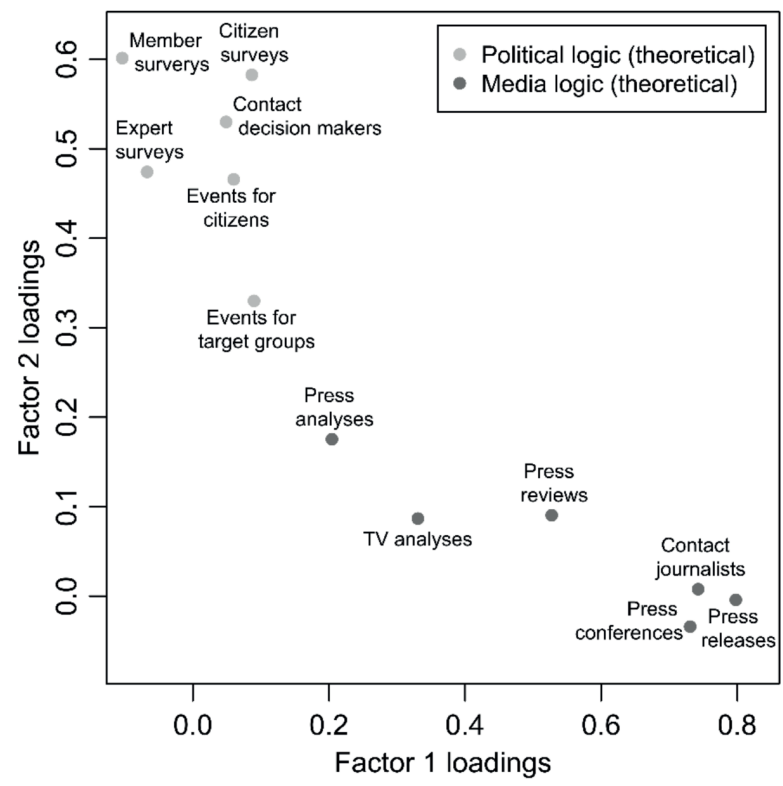

\section{Appendix C: Summary statistics and correlation}

In Table AI, summary statistics for all numerical variables used in the study are provided. In Figure A2, correlation statistics between the numerical variables used in this study are represented.

In addition to the variables described in the table, the three categorical variables country, group type, and issue area are used in this article. As already mentioned, the country variable is split into 494 observations from Switzerland, and 446 from Germany. The group type variable, as explained in the main text, has 262 of the organisations were coded as cause groups (II8 from Switzerland and I 44 from Germany) and 482 as specific in- terest groups (260 in Switzerland and 222 in Germany). The category coded as "Others" (according to Binderkrantz 2008) consequentially has 196 entries (II6 from Switzerland and 80 from Germany. For the issue area variable, a host of issues were coded (see Table 2 in the main text), most prominently economic issues (312 observations) and social issues (I24 observations).

Figure A2: Correlation matrix for all numeric variables used in the analysis

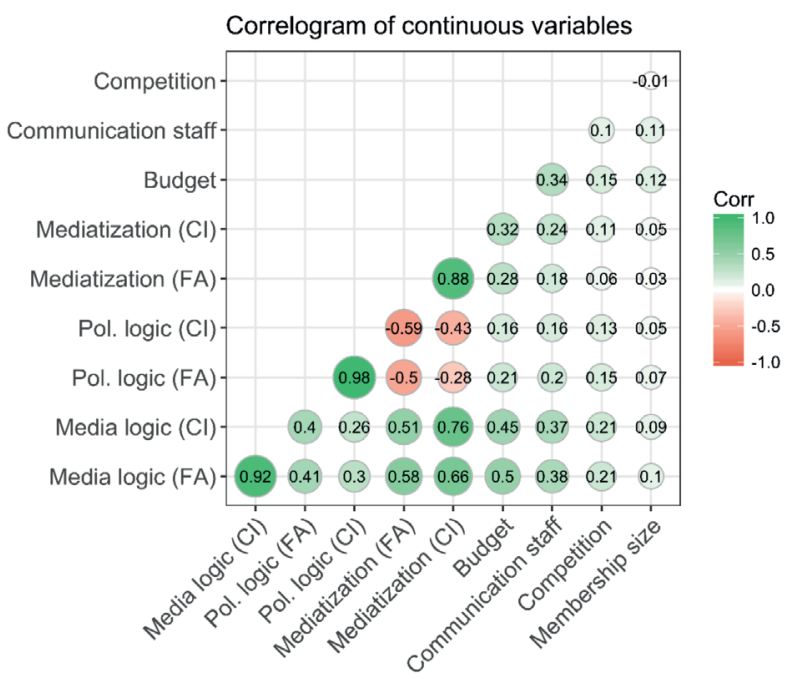


Table A1: Summary statistics for all numerical variables

\begin{tabular}{|c|c|c|c|c|c|c|c|c|}
\hline & Mean & SD & Median & Min & Max & Skew & Kurtosis & Valid $n$ \\
\hline Media logic index (FA) & -0.02 & 0.84 & -0.07 & -1.49 & 2.22 & 0.34 & -0.52 & 940 \\
\hline Media logic index $(\mathrm{Cl})$ & 0.27 & 0.18 & 0.27 & 0.00 & 0.83 & 0.59 & -0.02 & 940 \\
\hline Political logic index (FA) & 0.03 & 0.80 & 0.02 & -1.86 & 2.89 & 0.26 & -0.13 & 940 \\
\hline Political logic index (Cl) & 0.29 & 0.13 & 0.30 & 0.00 & 0.77 & 0.25 & -0.17 & 940 \\
\hline Mediatization index (FA) & -0.06 & 0.89 & -0.08 & -3.53 & 2.97 & 0.20 & 0.16 & 940 \\
\hline Mediatization index $(\mathrm{Cl})$ & -0.02 & 0.19 & -0.03 & -0.63 & 0.70 & 0.43 & 0.10 & 940 \\
\hline Budget * & 12.62 & 2.14 & 12.61 & 6.91 & 20.50 & -0.08 & -0.12 & 940 \\
\hline Communication staff * & 0.68 & 0.73 & 0.69 & 0.00 & 5.71 & 1.98 & 7.02 & 940 \\
\hline Competition* & 2.69 & 0.96 & 3.00 & 1.00 & 5.00 & 0.21 & -0.35 & 940 \\
\hline Membership size* & 5.37 & 2.83 & 5.35 & 0.00 & 14.81 & 0.18 & 0.16 & 940 \\
\hline
\end{tabular}

* denotes logarithmized variables 
